\title{
Middle Miocene bovids from Mae Moh Basin, Northern Thailand: The first record of the genus Eotragus from Southeast Asia
}

Kantapon Suraprasit, Yaowalak Chaimanee, Olivier Chavasseau, and Jean-Jacques Jaeger Acta Palaeontologica Polonica 60 (1), 2015: 67-78 doi: http://dx.doi.org/10.4202/app.2012.0061

We describe the first bovid fossils from the late middle Miocene (13.4-13.2 Ma) of the Mae Moh Basin of Northern Thailand, and assign the material to the new species Eotragus lampangensis sp. nov., Eotragus cf. lampangensis, and an indeterminate bovid. Our material represents the first report of Eotragus from Southeast Asia, thus greatly extending the geographic distribution of this genus across the Old World continents. While comparisons of the Southeast Asian specimens with abundant material of E. clavatus from Sansan (France) and E. aff. clavatus from Tarazona de Aragón (Spain) indicate a high degree of intraspecific variation within single species of Eotragus , the existence of two distinct taxa at Mae Moh remains a possibility. Based on previous carbon isotope studies of Mae Moh herbivore tooth enamel, Eotragus lampangensis sp. nov. foraged predominantly in an ecotone between grassland and forest.

Key words: Mammalia, Bovidae, Eotragus, Miocene, Southeast Asia, Thailand, Mae Moh Basin.

Kantapon Suraprasit [suraprasit@gmail.com, kantapon.suraprasit@univ-poitiers.fr ], Yaowalak Chaimanee [yao.chaimanee@univ-poitiers.fr], Olivier Chavasseau [olivier.chavasseau@univ-poitiers.fr], and Jean-Jacques Jaeger [jean-jacques.jaeger@univ-poitiers.fr], Institut International de Paléoprimatologie et de Paléontologie Humaine: Evolution et Paléoenvironnements, UMR CNRS 6046 Université de Poitiers, 6 rue Michel Brunet, 86022 Poitiers, France.

This is an open-access article distributed under the terms of the Creative Commons Attribution License (for details please see creativecommons.org), which permits unrestricted use, distribution, and reproduction in any medium, provided the original author and source are credited. 
Farf Full text (467.0 kB) ।

Forf Supplementary file $(138.7 \mathrm{kB})$ 